\title{
Bacteriological water quality in school's drinking fountains and detection antibiotic resistance genes
}

\author{
Denize Gomes Freitas ${ }^{1}$, Rassan Dyego Romão Silva ${ }^{3}$, Luis Artur Mendes Bataus², Mônica Santiago Barbosa ${ }^{3}$, \\ Carla Afonso da Silva Bitencourt Braga ${ }^{3}$ and Lilian Carla Carneiro $3,4^{*}$ (D)
}

\begin{abstract}
The fecal coliform can contaminate water of human consumption causing problems to public health. Many of these microorganisms may contain plasmid and transfer them to other bacteria. This genetic material may confer selective advantages, among them resistance to antibiotics. The objectives of this study were to analyze the presence of fecal coliforms in water and at drinker surface, to identify the existence of plasmid, conducting studies of resistance to antibiotics, plasmid stability and capacity of bacterial conjugation. Were collected microorganisms in water of drinker surface and were used specific culture media and biochemical tests for identification of organisms, tests were performed by checking the resistance to antibiotics (ampicillin $10 \mu \mathrm{g}$, tetracycline $30 \mu \mathrm{g}$, and ciprofloxacin $5 \mu \mathrm{g}$ ), was performed extraction of plasmid DNA, plasmid stability and bacterial conjugation. Was obtained results of $31 \%$ of Salmonella spp. and 51\% for other coliforms. Among the samples positive for coliforms, 27 had plasmid stable and with the ability to perform conjugation. The plasmids had similar forms, suggesting that the resistance in some bacteria may be linked to those genes extra chromosomal.
\end{abstract}

Keywords: Microorganism, Plasmid stability, Bacterial conjugation, Contaminants, Water, Health

\section{Background}

Water is essential to life, but many people do not have access to clean and safe drinking water and many die of waterborne bacterial infections. Understanding water quality is vital to worldwide public health. The access to potable water increases the lifespan and improves the health of world citizens. Several diseases can be provoked by pathogenic microorganisms found in contaminated water [1]. The Ministry of Health (Ministério da Saúde 200) by ordinance 518, resolution number 20 of 1986 of CONAMA (National Council for the Environment), provides that water for human consumption must be free of microorganisms having a patterning acceptable with values of $200 \mathrm{CFU} / 100 \mathrm{~mL}, 1000 \mathrm{un} / 100 \mathrm{~mL}$ and $4000 \mathrm{un} / 100 \mathrm{~mL}$ for thermo tolerant coliforms.

\footnotetext{
*Correspondence: carlacarneirolilian@gmail.com

${ }^{4} 235$ Street, Leste Universitário Neighborhood, Goiânia, GO 74605-050, Brazil

Full list of author information is available at the end of the article
}

The human activity produce contamination in water, the majority of microorganisms presents are coliforms, which indicates human or animal fecal contamination of water $[2,3]$.

Escherichia coli, Klebsiella sp. and Salmonella sp. are enterobacteria frequently isolated from human biological materials. Several outbreaks of food poisoning are associated with poor sanitation conditions such as failure of hand hygiene or bad cleaning [4-6]. Salmonellosis, one of the most commom diseases that can be transmitted by food, is caused by the bacteria salmonella [7-9].

The presence of Salmonella sp. in water can endanger human health, due the presence of antibiotic resistance genes [10]. Many antibiotic resistance genes reside on transmissible plasmids.

Important biological functions are associated with plasmids in Salmonella including virulence factors, resistance to heavy metals, antibiotics, phages and utilization of carbon sources [10]. The virulence plasmids 
usually have high molecular weight [11]. The dissemination of the plasmid may cause an increase in bacterial resistance [12], interfering with the clinical importance of infections by contributing to increased spread of antibiotic resistance genes [13].

The aim of this study was to assess the bacteriological water quality in school's drinking fountains and detection of cryptic plasmids harboring antibiotic resistance genes.

\section{Methods}

\section{Collection and cultivation of microorganisms}

The 110 biological samples used in this study were isolated from water and from drinking fountains surface in public schools of Morrinhos-GO. Were collected 51 samples from the button that controls the output of water, 51 from pipe where the water comes out and eight from water samples. A $10 \mathrm{~mL}$ aliquot was aseptically collected from each school visited. The samples from drinking fountains surfaces were obtained using swabs. The samples were cultivated in nutrient broth. After $24 \mathrm{~h}$ of incubation, samples were maintained at $4{ }^{\circ} \mathrm{C}$, and peaked monthly.

\section{Bacterial identification}

Were isolated samples from 51 troughs. The coliforms were identified by culture media, using the EC broth (Escherichia coli) and SS agar (Salmonella and Shigella media). After procedure the culture tests, the samples were conducted to biochemical tests: glucose [14], lactose [15] and Citrate's Simons [16].

\section{Antimicrobial susceptibility}

The antibiogram was performed through of methodology for disk of diffusion by Bauer \& Kirby, according the criteria established by the National Committee for Clinical Laboratory Standards [17]. The inoculation was circulated through of scan using swab on the surface of the Mueller-Hinton agar, then were placed discs of antibiotics (ampicillin $10 \mu \mathrm{g}$, tetracycline $30 \mu \mathrm{g}$ and ciprofloxacin $5 \mu \mathrm{g})$ in agar, with the assistance of sterile forceps. After placing the discs, the plates were inverted and incubated at $36{ }^{\circ} \mathrm{C}$ for $24 \mathrm{~h}$, latterly were analyzed through of inhibition halos to ampicillin considered resistant $(<14 \mathrm{~mm})$, intermediate $(14-16 \mathrm{~mm})$, sensitive $(>17 \mathrm{~mm})$; to tetracycline are resistant $(<14 \mathrm{~mm})$, intermediate $(15-$ $18 \mathrm{~mm}$ ), sensitive ( $>19 \mathrm{~mm}$ ) to ciprofloxacin are resistant $(<15 \mathrm{~mm})$, intermediate $(16-20 \mathrm{~mm})$, sensitive $(>21 \mathrm{~mm})$.

\section{Plasmid DNA extraction}

Based on the manual extraction kit FLEXIPREP of Pharmacia ${ }^{\circledR}$. Bacteria were grown overnight into $5 \mathrm{~mL}$ of Luria-Bertani medium and incubated at $37{ }^{\circ} \mathrm{C}$ under agitation of $150 \mathrm{rpm}$. An aliquot of $1.5 \mathrm{~mL}$ was separated and processed by extraction of plasmid DNA according manufacturer's protocol.

\section{Electrophoresis in agarose gel}

According to (Green and Sambrook, [18]) the samples of plasmid DNA were analyzed in agarose gel $1 \%(\mathrm{p} / \mathrm{v})$ colored with ethidium bromide, dissolved in TEB $0.5 \times$ and ethidium bromide $(0.2 \mu \mathrm{g} / \mathrm{mL})$. The gel was subjected to amperage of $30 \mathrm{~mA}$ until that sample to enter in the well, and then adjusted to $60 \mathrm{~mA}$. Were visualized the bands of plasmid DNA by ultraviolet radiation of low intensity. Were used a marker of weight molecular of $1 \mathrm{~Kb}$ DNA ladder from promega ${ }^{\circledR}$ for comparing the size of the fragments.

\section{Plasmid stability}

(1) The positive samples with cryptic plasmid, were inoculated in nutrient agar, supplemented with ampicillin and incubated at $37{ }^{\circ} \mathrm{C}$ overnight. (2) After incubation, $5 \mu \mathrm{L}$ from cultive, were diluted in $5 \mathrm{~mL}$ of nutrient without antibiotic and incubated at $37^{\circ} \mathrm{C}$ overnight, after growth, (3) aliquots supplemented with ampicillin and aliquots without ampicillin, were placed on nutrient $1.0 \%(\mathrm{p} / \mathrm{v})$ and incubated again at $37{ }^{\circ} \mathrm{C}$ overnight. The (2 and 3) procedure were repeated four times. The pLK39 plasmid was kindly provided by [19]. The pLK39 plasmid was the standard for comparison with the plasmid studied in this work.

\section{Conjugation}

The conjugation followed the method described by Mitsuhashi et al. [20], with modifications. The donor sample (coliform containing cryptic plasmids) and the receptors with characteristics lac $\mathrm{Z}$ negative (Escherichia coli $\mathrm{DH} 5 \alpha)$ were cultivation separately on L medium. After $18 \mathrm{~h}$, were mixed in two broths of cultivation, incubated the bacterial cultivation for $24 \mathrm{~h}$ and selected the trans conjugants plate ding on LA containing ampicillin and $\mathrm{X}$-Gal chromogenic. After growth, observed the appearance of blue and white colonies.

\section{Statistical test}

We used the statistical test Chi square, SYSTAT 13 to verify if the contamination of local of trough and water were in a high amount of contamination and if was differences between the sites of contamination.

\section{Results and discussion}

Among the 110 samples obtained, 21 were negative (three of water, eight by button that controls the water output and ten of pipes), 89 samples showed microbial 
Table 1 Profile of bacterial sensitivity antimicrobials tested

\begin{tabular}{llll}
\hline Antibiotic & Resistant (\%) & Intermediate (\%) & Sensitive (\%) \\
\hline Ampicillin & 14.6 & 9 & 76.4 \\
Tetracycline & 7.9 & 10.1 & 82 \\
Ciprofloxacin & 3.4 & - & 96.6 \\
\hline
\end{tabular}

growth, (Table 1). Of the water samples from button that control the water output, in five of them were found contamination, however, no one was positive to fecal coliforms. Santana et al. [21], analyzed samples from trough of schools in the city of Brejo da Cruz, PB, and found 26\% of the samples contaminated by Escherichia coli.

In this study, among 89 positive samples (49.44\%) showed contamination by fecal coliforms and other $50.56 \%$ of the samples were contaminated by other bacteria (data not shown). Analyzing the surface samples of drinkers, found that $50 \%$ were positive for fecal coliforms, data similar to those of Silva et al. [22], who found positive for $58.82 \%$ of strains isolated from surface of trough. Among the samples classified in this article, $6.67 \%$ were Klebsiella sp. 12.22\% Escherichia coli and 31.11\% of Salmonella sp.

With analyze of the statistical data we conclude that the water contamination not was statistically significant $\left(\mathrm{x}^{2}=2, \mathrm{p}=0.16\right)$ in samples collected from the button of trough and of pipe, there was statistical difference of contamination $\left(\mathrm{x}^{2}=26.84, \mathrm{p}<0.0001 ; \mathrm{x}^{2}=18.84\right.$, $\mathrm{p}<0.000014)$. Performing a comparison between the contaminated sites concluded that the contamination rate is equal between the water and button, water and pipe, pipe and button (respectively, $\mathrm{x}^{2}=0.09, \mathrm{p}=0.77$; $\mathrm{x}^{2}=0.01, \mathrm{p}=0.90 ; \mathrm{x}^{2}=0.28, \mathrm{p}=0.59$ ).

Were performed tests of antibiogram in all samples and $85 \%$ them were sensitive to antibiotics (ampicillin, tetracycline and ciprofloxacin). The profile of bacterial sensitivity antimicrobials tested are $14.6 \%$ resistant to ampicillin, $7.9 \%$ resistant to tetracycline and $3.4 \%$

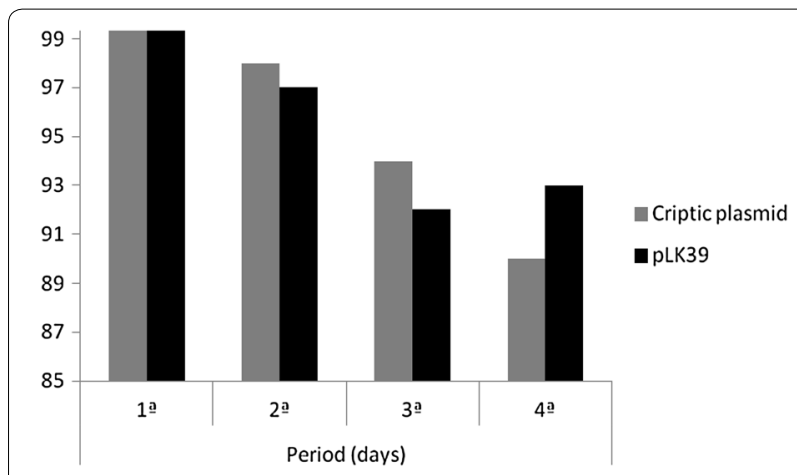

Fig. 2 Analysis of the stability of plasmids found in fecal coliforms

resistant to ciprofloxacin. The intermediate results show $9 \%$ to ampicillin and $10.1 \%$ to tetracycline.

The Gram-positive bacteria found are highly sensitive to penicillin and sulfonamides, as well as anionic detergents and resistance to sodium azide [23]. When analyzing the plasmids types, the interpretation of results obtained shown that the plasmids obtained are around $10 \mathrm{~Kb}$.

Studies developed by Akturk et al. [24], in fountain drinking water, showed contamination by Proteus vulgaris, Escherichia coli, Pseudomonas aeruginosa and Citrobacter spp. The antimicrobial susceptibility study, showed resistance to bacitracin, vancomycine, cephalothin and ampicillin. Plasmid DNA was isolated from 22 isolates; some of them contain a high-molecular weight plasmid DNA. Similar results were found in this study, where bacteria from fountain drinking water presented plasmid with molecular weight more than $10 \mathrm{~Kb}$. Based in this information's, suggest that the antibiotic resistance, found on bacteria isolated in this work are from plasmids (Fig. 1).

After to isolate and to characterize the plasmids, were done a plasmidial preparation to assess cryptic plasmid stability from coliforms samples found in this work. This information is important to certify if the bacteria that have the plasmid, have possibility of confer antibiotic resistance to future generations.

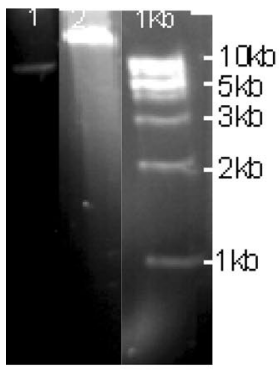

a

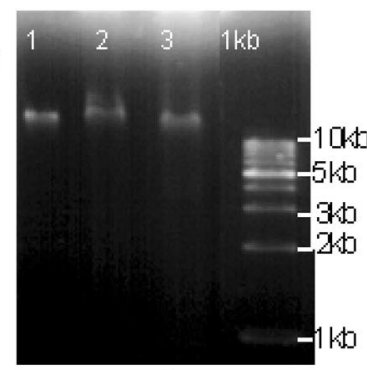

b

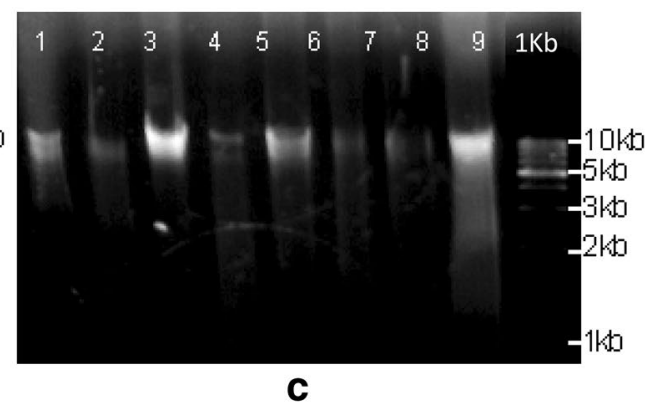

C

Fig. 1 Plasmidial DNA profile. The bands on $\mathbf{a}$, $\mathbf{b}$ and $\mathbf{c}$ represent the PCR amplification of plasmidial DNA profile 
The experiments were carried together with another plasmid (pLK39 containing the kanamycin resistance gene) and remained stable in cells of $E$. coli. The growth of the organism control in the plate with agar prevailed stable and coliforms samples had the same growth in score of CFU/ $\mathrm{mL}$, meaning that also remained stable. These data suggest that the plasmids have origin of replication independent and can be manipulated as biological vectors (Fig. 2).

Experimental results, showed that the plasmids isolated in this article are stable by generations. Associated at that information, is interesting to know if the bacteria are able of transfer the plasmidial DNA to others species or others bacterial genders. To answer this question, was investigated the ability of bacteria grow in the trans conjugants and was analyzed too the presence and the absence of ampicillin. The results obtained (data not shown) revealed that the conjugation plasmidial was efficient. Similar the our study, a work developed in samples of pond water of ducks, RS, found that Escherichia coli was able of to transfer the tet $B$ gene and tet $A$ gene to another recipient bacteria [25].

\section{Concluding remarks}

Taking in consideration the data of contamination found in this study and the impact of the microorganisms on public health, it's suggested that the surfaces of the troughs are disinfected with alcohol as a method cheaper, accessible, but also a rapid bactericidal which decontaminates bacillus of tuberculosis, fungi and viruses [26]. For microbial decontamination also suggests the use of hypochlorite, sodium or calcium due to the broad spectrum of activity, with low cost and quick action.

\section{Authors' contributions}

DGF and LCC analyzed the data and drafted the manuscript. DGF and LCC designed the study, and directed implementation and data collection. DGF collected the data, and LAMB, RDRS and CASB provided necessary logistical support. LCC, LAMB and CASB edited the manuscript for intellectual content and provided critical comments on the manuscript. All authors read and approved the final manuscript.

\footnotetext{
Author details

1 Biology Department, State University of Goiás UEG, Morrinhos, Brazil.

${ }^{2}$ Biophysic Department, Federal University of Goiás, Goiânia, Brazil. ${ }^{3}$ IPTSP Department, Federal University of Goiás, Goiânia, Brazil. ${ }^{4} 235$ Street, Leste Universitário Neighborhood, Goiânia, GO 74605-050, Brazil.
}

\section{Acknowledgements}

None.

\section{Availability of data and materials}

The article data can be on results section, included the tables and figures.

\section{Competing interests}

The authors declared that they have no competing interests.

\section{Funding}

FAPEG by scholarship to student.
Received: 26 October 2016 Accepted: 15 December 2016

Published online: 08 February 2017

\section{References}

1. Coelho DA, Silva PMF, Veiga SMOM, Fiorini JE. Avaliação da qualidade microbiológica de águas minerais comercializadas em supermercados da cidade de Alfenas MG. Rev Hig Alim. 2007;21(151):88-92.

2. Michelina AF, Bronharoa TM, Daréb F, Ponsanoc EHG. Qualidade microbiológica de águas de sistemas de abastecimento público da região de Araçatuba. Rev Hig Alim. 2006;20(147):90-5.

3. Ozgumus OB, Tosun I, Aydin F, Kilic AO. Horizontal dissemination of TEM- and SHV-Type Beta-lactamase genes carrying resistance plasmids amongst clinical isolates of enterobacteriaceae. Braz J Microbiol. 2008;39:636-43.

4. Casewell M, Phillips I. Hands as route of transmission for Klebsiella species. Brit Med J. 1977:2:1315-7.

5. Ou JT. The 90 kilobase pair virulence plasmid of Salmonella serovar Typhimurium coexists in strains with a plasmid of the 23 incompatibility groups. Microb Pathol. 1993;15:237-42.

6. Vicente ACP, Dias JCAR, Hofer E. Coliformes fecais em águas de esgoto, II; Transferência de marcadores e presença de plasmídeos. Engenharia sanitária. 1988;83:29-35.

7. Rychlik I, Gregorova D, Hradecka H. Distribution and function of plasmids in Salmonella enterica. Vet Res Inst. 2006;112:1-10.

8. Castagna SMF, Schwarz P, Canal CW. Presença de Salmonella sp. no trato intestinal e em tonsilas/linfonodos submandibulares de suínos ao abate. Arq Bras Med Vet Zootec. 2004;56(3):300-6.

9. Cortez LAL, Carvalho ACFB, Amaral LA, Salotti BM. Coliformes fecais, Estafilococos coagulase positiva (ECP), Salmonella spp. e Campylobacter spp. em linguiça frescal. Alim Nutr. 2004;15(3):215-20.

10. Bohez $L$, Dewulf J, Ducatelle R, Pasmans F. The effect of oral administration of a homologous hilA mutant strain on the long-term colonization and transmission of Salmonella Enteritidis in broiler chickens. Vaccine. 2008;26(3):372-778

11. Sidrim JJC, Moreira JLB, Paixão GC, Lima SB, et al. Multirresistência a antimicrobianos mediada por plasmídios R em cepas de Shigella flexneri isoladas no nordeste do Brasil. Rev Soc Bras Med Trop. 1998;31(3):263-70.

12. Gregorova D, Matiasovicova J, Sebkova A, Faldynova M, et al. Salmonella enterica subsp. enterica serovar enteritidis harbour ColE1, ColE2, and rolling-circle-like replicating. Vet Res Inst. 2004;50:107-12.

13. Oliveira AM, Gonçalves MO, Shinohara NKS, Stamford TLM, et al. Manipuladores de alimentos: um fator de risco. Hig Alim. 2003;17:114-5.

14. Hugh $\mathrm{R}$, Leifson $\mathrm{E}$. The taxonomic significance of fermentative versus oxidative metabolism of carbohydrates by various Gram-negative bacteria. J Bacteriol. 1953;66:24-6.

15. Mainil J. Escherichia coli virulence factors. Vet Imunol Imunopatol. 2013;152(1-2):2-12

16. Simmons JS. A culture medium for differentiating organisms of typhoidcolon aerogenes groups and for isolation of certain fungi. J Infect Dis. 1926:39:209-14.

17. National Committee for Clinical Laboratory Standards. Methods for dilution antimicrobial susceptibility tests for bacteria that grow aerobically. Approved Standard — ninth edition. CLSI document M07-A9. Wayne: Clinical and Laboratory Standards Institute; 2015. pp. 10-6.

18. Green MR, Sambrook J. Molecular cloning-a laboratory manual, vol. 1. Cold Spring Harbor: Cold Spring Harbor Laboratory Press; 2012.

19. Dourado PL, Cardoso VL, Coelho AS, Bataus LA. Sequence analysis and characterization of plasmid plk39 isolated from endophytic Salmonella sp. isolated from Solanum lycocarpum. Curr Microbiol. 2014;69:846-51.

20. Mitsuhashi S, Harada K, Hashimoto H. Multiple resistance of enteric bacteria e transmission of drug-resitance to other strain by mixed cultivation. Jap J Exp Med. 1960;30:179-84.

21. Santana FBF, Martins DSS, Oliveira JS, Nobrega AL. Análise microbiológica e bromatológica da água em bebedouros de escolas públicas em Belém do Brejo do Cruz-PB. Rev Verde. 2015;10(2):145-9. 
22. Silva N. Manual de métodos de análise microbiológica de alimentos. Valéria Christina: Livraria Varela; 1997. p. 31.

23. Rajagopal S, Eis N, Nickerson KW. Eight Gram-negative bacteria are 10,000 times more sensitive to cationic detergents than to anionic detergents. Can J Microbiol. 2003;49:775-9.

24. Akturk S, Dincer S, Toroglu S. Determination of microbial quality and plasmid-mediated multidrug resistant bacteria in fountain drinking water sources in Turkey. J Environ Biol. 2012;33(6):1127-36.
25. Aslam M, Diarra MS, Rempel H. Antimicrobial resistance genes in Escherichia coli isolates recovered from a commercial beef processing plant. J Food Prot. 2009;72(5):1089-93.

26. Kalil EM, Costa AJF. Desinfecção e esterilização. Acta Ortop Bras. 1994;2(4):1-4. 